\title{
The Analysis of the Effect of Determinant Factors of Palm Oil Plantation Sector on Agricultural Sector Growth in North Sumatera
}

\author{
Ali Sandy Hasibuan', Fitrawaty ${ }^{2}$, M. Fitri Rahmadana ${ }^{2}$ \\ ${ }^{1}$ Master Student in State University of Medan (Unimed), Medan, Indonesia \\ ${ }^{2}$ Lecturer in State University of Medan (Unimed), Medan, Indonesia \\ alisandyhasibuan@gmail.com
}

\section{Abstract:}

This study aims to analyze the influence of the area of oil palm plantations, oil palm production, and the number of the agricultural sector workforce on the agricultural sector PDRB in North Sumatra province. The data used are secondary data sourced from BPS North Sumatra province, namely PDRB variable in the agricultural sector, area of oil palm, palm oil production and the number of agricultural sector workforce in North Sumatra province in time series from 2008 to.d. 2017 in five districts namely, Asahan, Langkat, Labuhanbatu Utara, Labuhanbatu Selatan and Labuhan Batu districts. Data analysis was performed using the OLS (Ordinary Least Square) method with a panel data regression estimation model using the help of Eviews 10. The results of this study simultaneously showed that changes in the independent variables of land area, production and the total workforce of the agricultural sector together influenced Agricultural Sector PDRB variable significantly. While partially concluded that the variable area of land and oil palm production had a positive and significant effect on the PDRB of the agricultural sector in North Sumatra province, while the variable labor force in the agricultural sector had a negative effect on the PDRB of the agricultural sector in North Sumatra province.

Keywords

PDRB; land area;

production; labor force

\section{Introduction}

As the main oil palm producing region in Indonesia, North Sumatra province, has a significant contribution to the production of oil palm in Indonesia with an area of more than 450 thousand hectares with production of more than 15 million tons every year.

In general, land area has a direct effect on production, if land area increases, it will automatically increase production. However, at a certain time the planting area and production will not affect directly if there are several factors in it including planting age which directly affects production. According to Wahid and Simeh (2010), planting conditions that are old and unproductive will cause productivity to be low. Rejuvenation as an effort to replace old plants with new plants and is an annual crop management practice to maximize and stabilize income (Kotagama, et al., 2013). 


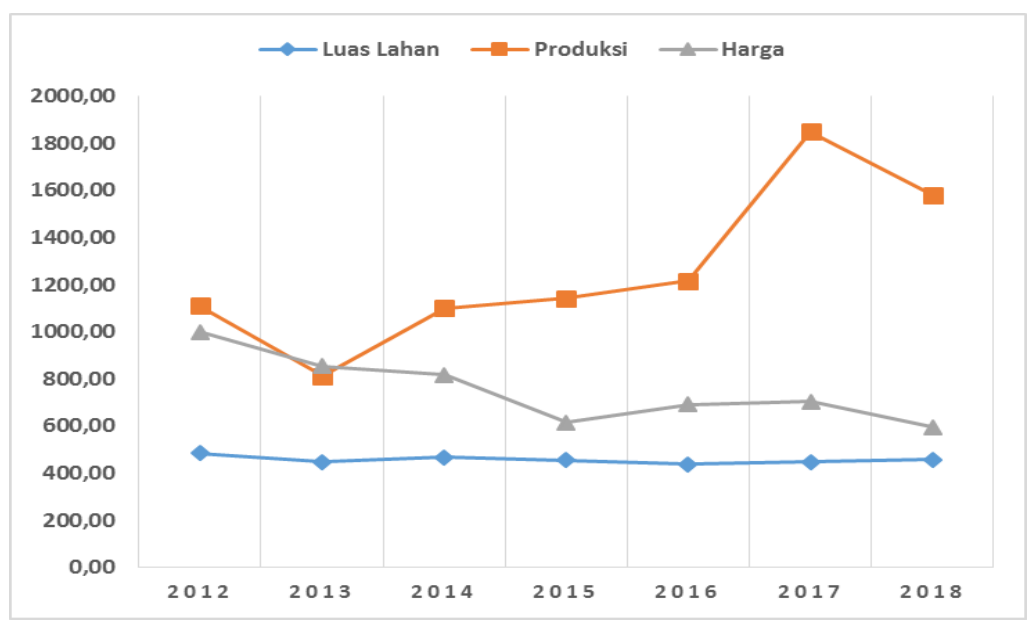

Figure1. Comparison of Land Area, Production and Price Palm Oil in North Sumatra 2012-2018

Source: North Sumatra BPS \& North Sumatra GAPKI (data processed)

From the picture above, it can be seen that there has been a fluctuating change in the price of oil palm and its production. Both affect each other, where if the price rises, production also rises so that revenue or income also increases. This is consistent with income theory. However, in 2013-2015 there was an increase in production even though prices declined or in other words the decline in price changes was smaller than the increase in changes in production. And in 2016-2017, there was an increase in prices and also an increase in production, but the change in price increases is smaller than the changes in production increases. This shows that in addition to prices that can affect production or output there are several other factors such as land area, labor and technology that can drive production increases amid falling oil palm prices.

Oil palm plantations not only make a significant contribution to the agricultural sector but also become an effective weapon in reducing poverty by stimulating and accelerating development in rural areas, especially in the North Sumatra regency. Much evidence can be conveyed that oil palm plantations have a positive effect on increasing income in rural areas. Providing permanent employment in oil palm plantations and industrial activities can stimulate economic activity and reduce poverty in rural areas. Oil palm plantations also provide opportunities for farmers and local residents to obtain greater fixed income. The development of an oil seed processing industry that is integrated with the plantation area creates employment opportunities for local communities (Chomitz and Buys, 2007).

The Malaysian Government's success story in resettling rural landless programs for oil palm expansion in small farmers is a key role in reducing poverty in rural areas. Poverty in rural areas decreased to $10 \%$ in just seven years from $21.8 \%$ in 1990 , down to $11.8 \%$ in 1997 . (Simeh et al., 1970, Brockington et al., 2008). Developing oil palm plantations provides investment opportunities in rural areas. Establishing large plantations by companies will encourage investment in rural areas. This will have an impact on economic improvement and infrastructure development in rural areas. Providing roads, electricity, water, housing, schools, medical facilities, transportation and communication by oil palm plantation companies can support the government in accelerating the development of rural areas (Koh and Wilcove, 2007). Easy access to transportation, education, markets and health has an impact on economic activities in the village and will reduce poverty naturally. 
Oil palm plantation land in North Sumatra Province is based on ownership divided into government property, private company, and people's property. BPS data shows that oil palm ownership in North Sumatra Province is $50 \%$ managed by the private sector, $30 \%$ by the people and $20 \%$ by the Government. Management of smallholder oil palm lands in North Sumatra is still centralized in terms of the largest plant and production area located in the districts of Asahan, North Labuhanbatu, Langkat, Labuhanbatu Selatan and Labuhanbatu districts.

In the last 5 years, the largest area of land and production is in the five regions of North Sumatra, namely Kab. Asahan, Labuhanbatu Utara, Langkat, Labuhanbatu Selatan and Labuhanbatu districts are the basis for selecting samples in this study. The production of the five main oil palm producing regions in North Sumatra has fluctuated. Regions such as the district of Asahan tend to increase and the other four regions tend to decrease. The area of oil palm in the five regions did not experience significant changes. The Gross Regional Domestic Product of the agricultural sector based on the constant prices of the five regions has increased every year. Likewise with the number of the workforce which is also experiencing annual growth.

\section{Review of Literature}

\subsection{Solow Growth Theory}

This theory explains how the level of savings and investment, population growth and technological progress affect the level of economic output and growth over time (Mankiw, 2000). In this theory technological development is assumed to be an exogenous variable.

According to Solow's theory there are a number of things being done to spur economic growth. Increasing the portion of savings will increase capital accumulation and accelerate economic growth. In addition, increasing investment is appropriate in the economy both in physical and non-physical forms. Encouraging technological progress can increase income per workforce so that the opportunity to innovate in the private sector will have a major influence on economic growth.

\subsection{Theory of Cobb-Douglas Production}

In economics which is called the production function which is a function that shows the relationship between physical output (output) with the factor of production (input), Daniel M (2002). In a simple mathematical form, the production function is written as follows:

$$
\mathrm{Y}=\mathrm{f}(\mathrm{x} 1, \mathrm{x} 2, \mathrm{x} 3, \ldots \ldots \ldots \ldots \mathrm{xn})
$$

Where, $\mathrm{Y}$ is the product of production and $\mathrm{x} 1$.. $\mathrm{xn}$ are the factors of production. Various production functions have been widely discussed in the literature. Among the production functions commonly discussed and used by researchers is the Cobb-Douglas production function. The Cobb-Douglas production function can be written as follows (Soekartawi 2003):

$$
\mathrm{Y}=\alpha \mathrm{X}_{1}^{\mathrm{b} 1}, \mathrm{X}_{2}^{\mathrm{b} 2}, \ldots \mathrm{X}_{\mathrm{n}}^{\mathrm{bn}} \mathrm{e}^{\mathrm{n}}
$$

Where, $\mathrm{Y}$ is the variable explained, $\mathrm{X}$ is the variable that explains, "a, $\mathrm{b}$ " is the estimated magnitude and e is the error rate. In the above equation the variable explained is the GRDP of the agricultural sector in North Sumatra and the variable that explains is the 
area of land, production and the number of working-age population in five districts of North Sumatra.

The equation above is often called the Cobb-Douglas production function. The CobbDouglas function was introduced by Charles W. Cobb and Paul H. Douglas in 1920. To facilitate the estimation of the above equation, the equation is broadly broadened and transformed into a linear form by logifying the equation (Soekartawi, 2003), namely:

$$
\log Y=\log a+b 1 \log X 1+b 2 \log X 2+b 3 \log X 3+b 4 \log X 4+b 5 \log X 5+e
$$

Because the completion of the Cobb-Douglas function is always logged and transformed into linear, the requirements for using the function include:

1. There are no zero observations. Because the logarithm of zero is a number whose amount is unknown (infinite).

2. In the production function it is assumed that there is no difference in the level of technology in each observation.

3. Every $\mathrm{X}$ variable in the perfect competition market. The difference in location (in the production function) such as climate is already included in the error factor (e).

\subsection{Business Field Sector}

Leading sector is certain to have greater potential to grow faster than other sectors in an area, especially the supporting factors towards the superior sector, namely capital accumulation, growth of absorbed workforce, and technological progress. The creation of investment opportunities can also be done by empowering the potential of leading sectors owned by the region concerned (Rachbini, 2001).

Leading sector as a sector that is very important in the economic development of a region does not only refer to the geographical location alone but to a sector that spreads in various economic channels so as to be able to move the economy as a whole. Leading sector is a sector that is able to encourage growth or development for other sectors, both sectors that supply inputs and sectors that use their output as input in the production process (Widodo, 2006).

According to Rachbini (2001) there are four conditions for a particular sector to become a priority sector, namely:

1. The sector must produce products that have a large enough demand so that the growth rate develops quickly as a result of the demand effect.

2. Because there is a technological change adopted creatively the new production function shifts with broader capacity development.

3. There must be an increase in investment returns from the production results of the priority sectors, both private and government.

4. The sector must develop so that it can influence other sectors.

\subsection{Oil Palm Plantations and Poverty Alleviation}

Many economists believe that economic growth is the key to reducing poverty especially in poor and developing countries. Increased growth will lead to an increase in income per capita of the poor. The problem is how people become poor. Hagenaars and De Vos (1988) explained that poor people are people who live below living standards. Poor people also have low-level education even in basic education. They also do not have access to health care. Poor people rarely talk about income, but instead focus on managing assets physical, human, social and environmental - as a way to overcome their vulnerability. In many areas, this vulnerability has a gender dimension (Nafziger, 2006). 
Commercializing agriculture by introducing and developing crops traded in rural areas is a sharp strategy in developing rural areas. Specialization of crop production using advanced technology will increase productivity and create specific markets on a national and international scale. Producing traded crops can attract investors to invest in rural areas. Wayne Nafziger (2006) explained, since the 1990s where the era of globalization and commercialization began, Multinational Companies invest and transfer technology, develop product collaboration with local researchers, train producers, introduce contract farming, and provide financial assistance for farmers and people. poor agribusiness people. and developing countries.

The process of planting paddyin this area is still done manually by the community that is the traditional way that usually farmers only use long ropes as a tool and benchmarks in estimating the distance between paddyseeds. The process of planting paddyin this area is still the same as before, using traditional methods. The difference lies in the process that has used the wage system and is no longer done as before, namely alternately between paddy land owners and carried out voluntarily which is used as a habit of the community in tightening the kinship and building a sense of togetherness among fellow citizens. (Pandapotan, 2019)

\section{Research Method}

This research was conducted in North Sumatra Province with 5 (five) districts as samples of the study areas, namely, Asahan, North Labuhanbatu, Langkat, South Labuhanbatu and Labuhanbatu districts. The data used in this study are quantitative data in the form of secondary panel data obtained from the Central Statistics Agency (BPS) of North Sumatra during the period 2008 to 2017 and North Sumatra GAPKI. According to Widarjono (2009) In testing data regression there are several types of tests in the classical assumption test including tests of linearity, autocorrelation, heteroscedasticity, multicollinearity and normality. However, not all classic assumption tests must be performed on every model. In the panel data model a classic assumption test is performed in the form of multicollinearity, heteroscedasticity, and autocorrelation tests according to (Widarjono, 2009). In testing this panel data regression model there are several tests of feasibility or significance including hypothesis testing, and the coefficient of determination (R-square) test. There are two types of hypothesis testing on the regression coefficients that can be done, namely the f-test and ttest. Good or bad a regression equation is determined by its R-squares which have a value between zero and one.

\subsection{Analysis}

\section{Discussion}

a. Classical Assumption Test

Multicollinearity

One way to detect multicoinier symptoms can be seen from the high R2 value, and there are more insignificant independent variables than significant independent variables or even none of the significant independent variables.

Table 1. Multicollinearity Test

\begin{tabular}{|c|c|c|c|}
\hline & LH & PR & POP \\
\hline LH & 1.000000 & -0.383099 & 0.024788 \\
\hline PR & -0.383099 & 1.000000 & 0.278784 \\
\hline POP & 0.024788 & 0.278784 & 1.000000 \\
\hline
\end{tabular}


Sumber: Output eviews 10

Based on the table above we can see that there are no variables that have a value of more than 0.8. So it can be concluded that there is no multicollinearity in the regression model.

Heteroscedasticity

Table 2. Heteroscedasticity Test

Dependent Variable: RESABS

Method: Panel Least Squares

Date: 12/16/19 Time: 21:54

\begin{tabular}{crrrr}
\hline \hline Variable & Coefficient & Std. Error & t-Statistic & Prob. \\
\hline \hline LH & -0.016647 & 0.012260 & -1.357868 & $\mathbf{0 . 1 8 1 8}$ \\
PR & 0.000477 & 0.000400 & 1.191712 & $\mathbf{0 . 2 4 0 1}$ \\
POP & -0.000245 & 0.001506 & -0.162887 & $\mathbf{0 . 8 7 1 4}$ \\
C & 1256.819 & 742.8166 & 1.691964 & 0.0981 \\
& & & &
\end{tabular}

To see heteroscedasticity in the equation model seen from the Prob value. each independent variable. If the value is greater than $\alpha=0.05$. Then it can be concluded that the equality model is free from heteroscedasticity. Based on table 4.4 above the Prob value. each independent variable> 0.05 . Then the conclusion is at the $95 \%$ confidence level, it can be said that there is no heteroscedasticity in the regression model.

\section{Autocorrelation}

Autocorrelation problems are caused by the relationship between residual correlations of one observation with the residuals of another observation. Detection of autocorrelation problems is done by the Durbin-Watson (DW) method.

Based on the estimation results of the model, it is known that the DurbinWatson (DW) value is 1.810702. The Durbin-Watson calculated value is compared with the Durbin-Watson Table value ( $\alpha=5 \%$, the number of observations (n) is 50 and the number of independent variables $(\mathrm{k})$ is 3$)$, then the calculated DW value is in the "no autocorrelation" region. Thus, at the level of $\alpha=5 \%$, the estimated model does not experience autocorrelation problems.

\section{b. Classical Assumption Test}

To determine the use of the Common Effect and Fixed Effect Model methods to be selected, a Chow test can be used (Gujarati, 2003).

Table 3. Chow Test Results

\begin{tabular}{cccc}
\hline \hline Effects Test & Statistic & d.f. & Prob. \\
\hline \hline Cross-section F & 62.032506 & $(4,42)$ & 0.0000 \\
Cross-section Chi-square & 96.632978 & 4 & 0.0000 \\
\hline \hline
\end{tabular}


Based on the table above, in the "Cross-section Chi-square" row Prob column. the value is $0.0000<0.05$. So at a 95 percent confidence level, the Chow test results show that the right model is used with the Fixed Effect Model (FEM).

Next will be tested between the Fixed Effect Model (FEM) and the Random Effect Model (REM) method. To determine the use of the FEM method or REM to be selected, the Hausman test can be used (Gujarati, 2003).

Table 4. Hausman Test Result

\begin{tabular}{|c|c|c|c|}
\hline Test Summary & $\begin{array}{l}\text { Chi-Sq. } \\
\text { Statistic }\end{array}$ & Chi-Sq. d.f. & Prob. \\
\hline Cross-section random & 15.460192 & 3 & 0.0015 \\
\hline
\end{tabular}

Based on the table above, the "Cross-section random" column Prob. the value is 0.0015 $<0.05$. So at a 95 percent confidence level, the Hausman test results show that the right model to use is also the Fixed Effect Model (FEM).

With the Fixed Effect (FEM) method, differences in characteristics between cross sections can be seen. Assuming, that intercepts are different between individuals, while the slope is the same between individuals.

Model Estimation Results

Estimation of the model using the Fixed Effect method regarding the effect of Land Area, Production and the Agricultural Sector Workforce, on the Sector GRDP. Agriculture shows results

$$
\mathrm{Y}=2796.375+0.069 \mathrm{LH}+\text { 0.002PR }-0.006 \mathrm{POP}
$$

Based on the estimation results above, it shows that the variable area of land and production has a positive influence on the GRDP of the Agriculture sector. while the agricultural sector labor force has a negative influence on the GRDP of the Agriculture sector in North Sumatra. Furthermore, economic analysis of the estimation results will be described in the next sub-chapter.

Estimation results in the five districts in North Sumatra province based on the highest regression coefficient are Langkat District with a regression coefficient of 3673,023, followed by Asahan Regency at 600.3604. The lowest regression coefficient is in North Labuhanbatu Regency of $-2039,108$, followed by Labuhanbatu Selatan Regency of $-1658,139$ and Labuhanbatu Regency of -576,1363 (see table 4.5).

\section{Test Statistics}

\section{Test $t$}

From the estimation results of the equation model in the form of fixed effects obtained $t$ value for each variable is as follows:

1. LH (land area) to Y (PDRB of the Agriculture Sector) t-value $=2.798020$ with a probability level of 0.0077 . This shows that the probability value is smaller than $\alpha=$ 0.05 , so that the LH variable is significant at a $95 \%$ degree of confidence can positively affect the Agricultural Sector PDRB (Y), which means that if there is an increase in LH 
by 1 percent, then the Agriculture Sector PDRB (Y) will increase by the coefficient of 0.069 percent, cateris paribus.

2. $\mathrm{PR}$ (production) to $\mathrm{Y}$ (PDRB of the Agriculture Sector) $\mathrm{t}$-value $=2.270312$ with a probability level of 0.0284 . This shows that the probability value is smaller than $\alpha=$ 0.05 , so that the PR variable is significant at the $95 \%$ degree of confidence will positively affect the Agriculture Sector PDRB (Y), which means that if there is an increase in PR by 1 percent, then the Agriculture Sector PDRB (Y) will increase by the coefficient of 0.002 percent, cateris paribus.

3. POP (Agriculture sector labor force) to Y (PDRB of the Agriculture Sector) t-value = 2.067989 with a probability level of 0.0448 . This shows that the probability value is smaller than $\alpha=0.05$, so the POP variable is significant at the $95 \%$ degree of confidence will negatively affect the PDRB of the Agricultural Sector (Y), which means that if there is an increase in POP by 1 percent, then the PDRB of the Agriculture Sector (Y) will experience a decrease by the coefficient of 0.006 percent, cateris paribus.

\section{Test $\mathrm{F}$}

The $\mathrm{F}$ test or simultaneous test is carried out to see the effect of the independent variables simultaneously or together on the dependent variable. From the estimation results of the model for PDRB Agriculture Sector (Y), the calculated F value of 53.19660 with a probability level of 0.0000 . This shows that the independent variable for PDRB of Agriculture Sector (Y), namely LH, PR and POP simultaneously and significantly together influences the dependent variable namely PDRB of Agriculture Sector (Y) at a degree of confidence of $95 \%$.

\section{Coefficient of Determination $\left(\mathrm{R}^{2}\right)$}

The coefficient of determination reflects the magnitude of the effect of changes in independent variables together in explaining changes in the dependent variable. The coefficient of determination is useful for measuring the closeness of relationships between variables in the model. The value of $\mathrm{R} 2$ ranges from 0 to 1 . If the value of $\mathrm{R} 2$ is getting closer to one, then the proposed model can be said to be good, because the variation of the dependent variable that can be explained by the independent variable is higher.

Estimation results show the coefficient of determination $\left(\mathrm{R}^{2}\right)$ is 0.898643 . This means, that $89.86 \%$ of changes in the PDRB of the Agriculture Sector in the five districts of North Sumatra Province in the period 2008-2017 can be explained by changes in Land Area, Palm Oil Production and Agriculture Sector Workforce. While the remaining $10.14 \%$ is explained by other variables outside the model.

\subsection{Discussion}

Estimation experiments are carried out on variables considered to affect the PDRB of the Agricultural Sector, such as Land Area, Palm Oil Production Head and Agriculture Sector Work Force. Significant estimation results are given for variable Area of Land, Palm Oil Production Head and Agriculture Sector Work Force.

\section{a. Land Area (LA)}

Land can be interpreted as land used for agriculture. So, not all land is agricultural land and vice versa, all agricultural land is land (Moehar, 2001). The agricultural sector can play a role in the national economy through the formation of PDRB. The agricultural sector in its production process requires the main production factor, namely land. According to 
Manuwoto (1991) land functions in general can be divided into 2, namely land functions for cultivation and protection activities. In this study more emphasis on its function for cultivation activities that have been determined in the development of agricultural production.

North Sumatra is one area that has a large area of oil palm in Indonesia with a growth of 27 percent in 2017. Based on data from the Directorate General of Plantations, the area of oil palm in North Sumatra continues to increase from 1.43 million hectares in 2015 to 1.77 hectares in 2019 with Asahan district having the largest area of land ownership, with an area of around 76 thousand hectares in 2017, a very significant increase since 2008 with an area of only around 50 thousand hectares. This is because the district government of Asahan has conducted a policy of clearing and expanding oil palm land with a growth rate of land area reaching 35 percent in 2009 in accordance with the mission of Asahan District point nine, namely to increase agricultural competitiveness in the broad sense of plantation-based development through socialization of regulations plantations to realize sustainable plantation development in Asahan Regency so that it impacts on the average value of the largest land area growth in North Sumatra with 5.12 percent during the 2009-2017 period, followed by North Labuhanbatu district at 4.63 percent, South Labuhanbatu district at 1 , 40 percent, Langkat district by 1.34 percent and Labuhan Batu district by 0.69 percent in the same period.

Based on the results of the study, the LH regression coefficient value is equal to 0.069166. This means that if the area of land increases by 1 percent, the PDRB of the agricultural sector will also increase by 0.07 percent. Conversely, if the area of land decreases by 1 percent then the PDRB of the agricultural sector will also decrease by 0.07 percent. The effect of this LH variable is positive and significant at 95 percent confidence level. These results are in accordance with the hypothesis and research by Mesra (2017) which states that land area has a positive and significant effect on PDRB of the Agriculture Sector, where the results show that land area has a positive and significant effect on PDRB in Kab. West Pasaman.

\section{b. Production (PR)}

From the five districts in this study, Langkat became the district with the largest palm oil production since 2009-2012 and in 2016-2017. With production of almost 700 thousand tons in 2017, and the highest achievement ever recorded in 2013 amounted to nearly 800 thousand tons. South Labuhanbatu Regency is a district with quite high production. More than 600 thousand tons were recorded in 2017. Had been the district with the highest production in North Sumatra in 2013-2015 with the highest production achievements in 2013 amounting to nearly 800 thousand tons. Labuhan Batu Regency with production of more than 500 thousand tons in 2017. Had experienced a significant decrease in 2014-2015 with production of only less than 100 thousand tons. Asahan Regency is a district with production that continues to increase from 2008-2017. Recorded in 2008, production was only less than 200 thousand tons to reach nearly 600 thousand tons in 2017, an increase of almost three times in the last 10 years. While Labuhan Batu Utara regency became the district with the lowest production of five districts in 2017 with production of more than 300 thousand tons in 2017. Had been the district with the highest palm oil production in 2008 which amounted to more than 800 thousand tons. Then decreased in the following year by 500 thousand tons and even reached less than 200 thousand tons in 2010-2014. This is due to the Local Government in Labuhan Batu Utara making policies and program support through (RTRWK, RPJMD) and the District Agriculture Office, the Food Security Agency and the Agricultural Counseling Agency regarding the transfer of balanced land functions between rice as a 
commodity that maintains food security in Labuhan Regency North Batu, and rubber and palm oil as one of the leading commodities to improve the economy in Labuhan Batu Utara.

Palm oil production growth during the period 2009-2017 experienced fluctuations, but when viewed from the average growth value, Labuhanbatu has the largest value of 47.81 percent, this is in accordance with Labuhanbatu's mission point four, namely to build a strong economy to ensure equitable prosperity community through expanding employment, increasing the quantity and quality of agricultural production, plantations, fisheries, animal husbandry, strengthening financial institutions and cooperatives as well as developing the potential of tourist areas. While Asahan district has an average production growth of 16.76 percent. Langkat Regency by 3.53 percent, Labuhanbatu Selatan Regency by 2.98 percent and Labuhanbatu Utara by -3.90 percent in the same period.

Based on the results of the study, the PR regression coefficient value is equal to 0.001832 . This means that if production increases by 1 percent, the PDRB of the agricultural sector will also increase by 0.002 percent. Conversely, if production falls by 1 percent then the PDRB of the agricultural sector will also decrease by 0.002 percent. The effect of this PR variable is positive and significant at 95 percent confidence level. These results are consistent with previous hypotheses and studies which state that production has a positive and significant effect on the PDRB of the Agricultural Sector. These results are consistent with research conducted by Pratama (2017) and Fitri (2019) which also concluded that production has a positive and significant influence on the PDRB of the agricultural sector.

\section{c. Agriculture Sector Workforce (POP)}

According to Arfida (2003), workers are working-age population who are able to produce goods and services to meet the needs of the community. Susanto (2012) concluded that the number of workers influential in producing goods or services that will be contributed to the PDRD.

In general the number of the agricultural sector workforce in the five districts in the study tended to decrease in the last 10 years. Where Asahan and Langkat regencies with the highest labor force in 2017 amounted to more than 150 thousand inhabitants. While Labura, Labusel and Labuhan Batu districts had a workforce in the agricultural sector of less than 100 thousand in 2017. On average, the growth in the number of agricultural sector workers in five districts during the period 2009-2017 only Asahan and Langkat Districts experienced an increase, respectively 1.51 percent and 7.43 percent. Whereas for the other three districts, namely Labuhan Batu Utara Regency, Labuhan Batu Selatan Regency and Labuhanbatu Regency experienced decreases of -7.65 percent, -7.16 percent and -2.78 percent respectively. The decline occurred due to the transition from labor-based regional economic activities to capital-intensive ones that rely more on capital, machinery and technology.

In this case industry 4.0 was formulated by Aount (MIT: 2017), namely data literacy, technological literacy and human literacy. Data literacy is the ability to read, analyze, and use information in the digital world. Technology literacy is to understand the workings of machines, the application of technology known as coding, Engineering Principles and Artificial Intelligence. Human literacy is literacy which emphasizes aspects of humanities, communication and design. It means that humans have leadership skills, team work, but not only that, understanding the culture and spirit of entrepreneurship.

Based on the results of the study, the POP regression coefficient value is equal to 0.006281 . This means that if the labor force in the agricultural sector increases by 1 percent, the GRDP of the agricultural sector will decrease by 0.006 percent. Conversely, if the labor force in the agricultural sector drops by 1 percent, the PDRB of the agricultural sector will increase by 0.006 percent. The influence of this POP variable is negative and significant at 95 
percent confidence level. These results are not in accordance with the hypothesis and previous research which states that the number of the agricultural sector workforce has a positive and significant effect on the PDRB of the Agricultural Sector. These results are consistent with Syaiful's research (2017) which states that the variable of labor has a negative and significant effect on economic growth in Yogyakarta.

\section{Conclusion}

From the results of the study and estimation it can be concluded as follows:

1. Land Area and Smallholder Palm Oil Production in five districts of North Sumatra have a positive and significant effect on the PDRB of the Agriculture Sector in North Sumatra Province, while the number of the Agricultural Sector Workforce of five districts in North Sumatra has a negative and significant effect on the PDRB of the Agriculture Sector in North Sumatra Province.

2. Estimation results show that the Land Area variable has the greatest influence on the PDRB model of the Agriculture Sector compared to the variable Number of Workforce in the Agriculture Sector and Oil Palm Production in five districts of North Sumatra.

\section{References}

Adelman, I. and Sherman R. (1986). Planning for Income Distribution: The Case of Korea. Stanford: Stanford Press.

Afrida, B.R. (2003). Ekonomi Sumber Daya Manusia. Jakarta. Ghalia Indonesia.

Aoun, J.E. (2017). Robot-proof: higher education in the age of artificial intelligence. US: MIT Press.

Basuki, A.T. (2014) Regresi Model Pam, Ecm dan Data Panel dengan Eviews 7. Yogyakarta: Katalog Dalam Terbitan (KDT).

Brockington, D.R.D. and J. Igoe (2008). Nature Unbound: Conservation, Capitalism and the Future of Protected Areas. Routledge.

Chomitz, K.M. and P. Buys. (2007). At Loggerheads?: Agricultural Expansion, Poverty Reduction, and Environment in the Tropical Forests: World Bank Publications.

Daniel, M. (2002). Pengantar Ekonomi Pertanian. Penerbit Bumi Aksara: Jakarta

Gujarati, D.N. (ed.) (2003) Basic Econometrics. (Fourth edn) New York, NY:McGraw-Hill, Inc.

Hagenaars, A. and K. De Vos. (1988). The Definition and Measurement ofPoverty'. Journal of Human Resources, pp 211-221.

Koh, L.P. and D.S. Wilcove. (2007). Cashing in Palm Oil for Conservation. Nature, 448 (7157): 993-994.

Kotagama H.B., Al-Alawi A.J.T., Boughanmi H., Zekri S., Jayasuriya H., and Mbaga M. (2013). Economic Analysis Determining The optimal Replanting Age of Date palm. Agricultural and Marine Sciences, 18: 51-61.

Mankiw, N.G. (2012) 'Macroeconomics 5th Ed'.

Manuwoto. (1991). Peranan Pertanian Lahan Kering di dalam Pembangunan Daerah. Erlangga: Jakarta.

Mesra, M.S. (2017). Analisis Dampak Perkebunan Kelapa Sawit Terhadap Perekonomian Wilayah Di Kabupaten Pasaman Barat. Jurnal Fakultas Ekonomi, 13 (3).

Moehar. (2001). Pengantar Ekonomi Pertanian. Bumi Aksara: Jakarta. 
Nafziger W.E. (2006). Economic Development 4th ed. Cambridge: Cambridge University Press.

Pandapotan, S. (2019). Social Capital as a Local Wisdom of Farmer in Managing Agricultural Resources in Lubuk Pakam Sub-district, Deli Serdang District. Budapest International Research and Critics Institute (BIRCI-Journal) : Humanities. P,469-476.

Rachbini, D.J, (2001). Pembangunan Ekonomi \& Sumber Daya Manusia. Gramedia Widiasarana Indonesia. Jakarta.

Simeh, A., M.P.O. Board and Ahmad, T.M.A.T. (1970). TheCase Study on the Malaysian Palm Oil. Crops, 1985 (1990): 1995-2000.

Soekartawi. (2003). Teori Ekonomi Produksi dengan Pokok Bahasan Analisis Cobb-Douglas. Jakarta : PT RajaGrafindo Persada.

Sumarsono, S. (2003). Ekonomi Manajemen Sumber Daya Manusia dan Ketenagakerjaan. Yogyakarta : Graha Ilmu.

Susanto, A. (2012). Analisis Angkatan Kerja dan Kontribusinya terhadap Produk Domestik Regional Bruto (PDRB) Jawa Tengah Tahun 2010 dengan Aplikasi Sistem Informasi Geografis. Publikasi Ilmiah. Surakarta: Program Studi Geografi Universitas Muhammadiyah Surakarta.

Syaiful, F.H. (2017). Analisis Pengaruh Investasi, Tenaga Kerja dan Tingkat Pendidikan terhadap Pertumbuhan Ekonomi di Daerah Istimewa Yogyakarta periode tahun 20092015. Skripsi. Yogyakarta: Program Studi Ekonomi Syariah Fakultas Ekonomi dan Bisnis Islam UIN Sunan Kalijaga.

Wahid M.B and Simeh M.A. (2010). Accelerated Oil Palm Replanting: The Way Forward For A Sustainable and Competitive Industry. Oil Palm Industry Economic Journal, 10 (2): 29-38.

Wayan, R.S. (2004). Contribution of oil palm industry to economic growth and poverty alleviation in Indonesia. Jurnal Litbang Pertanian, 23 (3): 107-114.

Widarjono, A. (2009). Ekonometrika: Teori dan Aplikasi Untuk Ekonomi dan Bisnis, edisi kedua. Yogyakarta: Ekonisia FE Universitas Islam Indonesia.

Widodo, Tri. (2006). Perencanaan Pembangunan. Aplikasi Komputer (Era Otonomi Daerah). UUP STIM YKPN. Yogyakarta 